\title{
Pengembangan Modul Komikadp untuk Mengurangi Kekerasan dalam Pacaran pada Siswa SMA
}

\author{
Cici Yulia ${ }^{* 1}$, Khoirunnissa Khoirunnissa ${ }^{2}$, Eka Heriyani ${ }^{3}$ \\ 1,2,3 Program Studi Bimbingan dan Konseling, Universitas Muhammadiyah Prof. Dr. \\ HAMKA, Jakarta, Indonesia. \\ *)1Corresponding author, ఏe-mail: ciciyulia165@gmail.com
}

\begin{tabular}{ccc}
\hline Received: & Accepted: & Published: \\
27 July 2021 & 1 October 2021 & 31 December 2021 \\
\hline
\end{tabular}

\begin{abstract}
There are many cases of dating violence in the world and in Indonesia due to lack of of awareness and misinterpreting dating violence as a form of love. The aim of this research is to produce the Komikadp module. The research method used is Research and Development (R\&D) method. The research and development model used is 4D Models which was depeloved by Sivasailam Thiagarajan, Dorothy S Semmel, and Melvyn I Semmel. This Model includes four stages, namely, define; design; develop; and disseminate. However, current research and development, used three phases; define, design, and development held at SMA Muhammadiyah DKI Jakarta. Data collection used a checklist as quantitative data and descriptions as qualitative data on the assessment sheet. The Komikadp module that has gone through the three stages received a decent assessment on the aspects of content feasibility, presentation feasibility, language, comic approach in accordance with the guidance and counseling assessment, and graphics based on expert tests and field tests. Thus, the Komikadp Module is very feasible when used by high school studies.
\end{abstract}

Keywords: Module, Komikadp, Dating Violence

\begin{abstract}
Abstrak
Banyak terjadi kasus kekerasan dalam pacaran di dunia dan di Indonesia karena kurangnya kesadaran dan salah menafsirkan kekerasan dalam pacaran sebagai bentuk cinta. Tujuan kajian untuk menghasilkan modul Komikadp untuk mengurangi kekerasan dalam pacaran. Studi dan pengembangan atau research and development (R\&D) adalah metode studi yang digunakan. Model studi dan pengembangan yang digunakan yaitu 4D Models mencakup empat tahap yaitu define, design, develop, dan disseminate. Namun, pada artikel ini dibatasi sampai tahap ketiga saja yaitu define, design, dan develop. Dilaksanakan di SMA Muhammadiyah DKI Jakarta. Pengumpulan data menggunakan daftar ceklis sebagai data kuantitatif dan uraian sebagai data kualitatif pada lembar penilaian. Modul Komikadp adalah Modul yang berisi materi tentang kekerasan dalam pacaran dan Komikadp yang didalamnya terdapat cerita tentang kekerasan dalam pacaran. Modul Komikadp yang sudah melalui ketiga tahap tersebut mendapat penilaian sangat layak pada aspek kelayakan isi, kelayakan penyajian, bahasa, pendekatan komik sesuai dengan penilaian Bimbingan dan Konseling, dan kegrafikan berdasarkan uji ahli dan uji lapangan. Sehingga, Modul Komikadp sangat layak apabila digunakan oleh studi SMA.
\end{abstract}

Kata Kunci: Modul, Komikadp, Kekerasan dalam Pacaran

This is an open access article distributed under the Creative Commons Attribution License, which permits unrestricted use, distribution, and reproduction in any medium, provided the original work is properly cited. (C2021 by author. 


\section{PENDAHULUAN}

Berpacaran atau hubungan romantis sangat penting dalam kehidupan sosial banyak remaja dan berkontribusi untuk memperkuat identitas (Cava et al., 2020). Sayangnya, pacaran menimbulkan masalah baru, diantaranya kekerasan dalam pacaran. Kekerasan dalam hubungan sangat umum terjadi dalam segala bentuk (Wekerle \& Wolfe, 1999). Bahkan, kekerasan domestik tidak hanya terjadi pada pasangan suami istri atau heteroseksual saja namun, kepada pasangan yang berpacaran, anak, hingga orang tua (Safira, 2019). WHO atau World Health Organization menyampaikan beberapa bentuk kekerasan fisik dan seksual oleh pasangan dialami hampir sepertiga $(27 \%)$ wanita berusia 15 49 tahun yang telah menjalin (World Health Organization, 2021). Di Indonesia sendiri, menurut catatan tahunan (CATAHU) KOMNAS Perempuan tahun 2020 menemukan kasus kekerasan dalam pacaran sebanyak 1.815 kasus, secara konsisten selama 3 tahun ini kekerasan seksual oleh pacar merupakan paling tinggi. Kekerasan dalam pacaran (dating violence) biasa juga disebut sebagai kekerasan pasangan intim (intimate partner violence) didefinisakan sebagai kekerasan fisik (misalnya menampar, meninju, menendang), agresi psikologis (misalnya berteriak, memalukan, dan menyebut nama), kekerasan seksual (misalnya pemaksaan seksual dan perhatian seksual yang tidak diinginkan), menguntit (yaitu perhatian yang tidak diinginkan yang menyebabkan ketakutan atau kekhawatiran akan keselamatan seseorang), atau kombinasi dari satu atau lebih dalam hubungan intim (Duval et al., 2018). Setyawati menyampaikan bahwa dampak pada fisik seperti patah tulang, memar, dan dalinnya serta luka psikis seperti terlukanya harga diri, perasaan terhina, sakit hati dan lainnya merupakan akibat kekerasan dalam pacaran (Wulandari, 2013).

Remaja merupakan kelompok usia yang sering mengalami kekerasan dalam pacaran. Kelompok usia dengan resiko tertinggi mengalami kekerasan dalam pacaran adalah kelompok usia 20 sampai dengan 24 tahun dan 12 sampai dengan 15 tahun sedangkan pada urutan pertama yaitu 16-19 tahun (Khaninah \& Widjanarko, 2016). Remaja yang sering menjadi korban kekerasan berhubungan dengan kecemasan, keadaan psikis yang berbahaya, tanda depresi, dan rendahnya kepercayaan diri (Carrascosa \& Ortega-bar, 2020). Malonda menyebutkan kurangnya pengalaman di hubungan romantis serta kurangnya kesadaran bahwa perilaku tersebut adalah bentuk perilaku kekerasan, sehingga remaja menganggap itu ekspresi cinta (Cava et al., 2020). Mengingat hal tersebut, kekerasan dalam pacaran perlu dikurangi dan dicegah supaya tidak mengalami dampak kekerasan berhubungan dan bisa memiliki kesadaran kekerasan dalam pacaran.

Sejalan dengan fungsi Bimbingan dan Konseling diantaranya fungsi pengentasan dan fungsi pencegahan (Amti, 
2008). Fungsi tersebut dijalankan melalui layanan yang diberikan. Bimbingan dan Konseling perlu melakukan layanan untuk mengurangi kekerasan dalam pacaran. Layanan dalam Bimbingan dan Konseling akan lebih efektif apabila menggunakan media (Prasetiawan, 2017). Contoh media salah satunya adalah modul (Lara, 2021). Menurut Daryono Di dalam modul terdapat rencana pengalaman-pengalaman belajar dan didesain sehingga membantu penggunannya bisa mencapai tujuan belajar yang spesifik secara utuh dan sistematis (Lara, 2021). Sejalan dengan penelitian yang dilakukan Nur Intan Fitriani dan Beni Setiawan di Mojokerto tentang “Efektivitas Modul IPA Berbasis Etnosains Terhadap Peningkatan Keterampilan Berpikir Kritis Siswa" dengan hasil angket respon siswa sebesar 95\% dengan kategori sangat baik. Studi ini bertujuan menghasilkan modul yang memuat tentang kekerasan dalam pacaran. Menurut Arum salah satu karakteristik modul adalah user friendly (Lara, 2021). Sehingga, modul yang digunakan haruslah sesuai dengan remaja SMA. Menurut American College of Pediatricians remaja berada pada tahap perkembangan dengan karakteristik menyukai media dengan unsur visual (Nugraha, 2017). Komik adalah salah satu bentuk komunikasi visual (Maharsi, 2011). Keterangan tersebut sesuai dengan studi yang dilakukan oleh (Nugraha, 2020) di Semarang dengan judul "Pengembangan Komik Kimia sebagai Media Pembelajaran Berbasis CET (Chemo-Edutaintment)" studi ini menunjukan media komik yang digunakan berpengaruh kepada hasil belajar dan kreativitas peserta didik. Studi tersebut juga sesuai dengan studi yang dilaksanakan oleh (Wulandari et al., 2020) "Pengembangan Modul Komik Pendidikan Kesehatan Reproduksi Terhadap Peningkatan Pengetahuan dan Sikap Remaja Tentang Dampak Seks Pranikah di SMAN 2 Singaraja Kabupaten Buleleng Provinsi Bali" Hasil dari studi yaitu peningkatan pengetahuan dan sikap remaja dipengaruhi oleh pemberian modul komik dan leaflet tentang akibat seks pranikah.

Teori kognitif multimedia learning Mayer sesuai studi-studi tersebut. Dimana menurut teori tersebut lebih banyak solusi kreatif pada tes transfer $89 \%$ apabila menggunakan kata-kata dan gambar dibandingkan siswa yang hanya beajar dengan kata-kata saja (Suparman et al., 2020). Komik edukatif dalam hal ini Komikadp yang berada dalam Modul Komikadp adalah media yang fleksibel bagi remaja, karena memiliki bahasa visual yang universal (Anwar, 2020)

Dari pemaparan tersebut bisa diketahui bahwa permasalahan timbul karena kurangnya pemahaman bentuk kekerasan dalam pacaran yang kerap dialami oleh korban. Sering terjadinya kekeliruan dalam memahami bentuk kasih sayang yang diberikan pacar terhadapnya sehingga apapun yang dilakukan oleh pacarnya itu merupakan kasih sayang, meskipun ia merasa tertekan dan tersakiti. Oleh sebab itu, untuk memberikan pemahaman kepada remaja yang memiliki resiko tertinggi mengalami kekerasan dalam pacaran dibutuhkan Modul Komikadp. Modul Komikadp yaitu Modul 68 
yang didalamnya berisi materi kekerasan dalam pacaran dan Komikadp. Komikadp adalah bentuk komunikasi yang berisi pesan kekerasan dalam pacaran yang disajikan dalam bentuk media grafis dengan menggunakan cerita bergambar.

\section{METODE}

Studi ini menggunakan Metode research and development (R\&D). Metode penelitian yang digunakan untuk menghasilkan produk tertentu, dan menguji keefektifan produk tersebut adalah metode penelitian dan pengembangan (Sugiyono, 2013). Model pengembangan yang digunakan adalah model pengembangan $4 \mathrm{D}$ atau Four $D$ Models yang dikembangkan Sivasailam
Thiagarajan, Dorothy S Semmell, dan Melvyn I Semmel. Terdiri dari tahap define, design, develop, dan disseminate (Thiagarajan, 1974). Namun, pada tahap disseminate memerlukan banyak waktu demi konsistensi produksi untuk disebar luaskan dan banyak biaya untuk menjaga produksi dan konsistensi dari kualitas produk serta memerlukan beberapa kebutuhan lain untuk tahap distribusi. Sayangnya, karena keterbatasan waktu dan biaya, studi ini hanya sampai pada tahap develop.

Subjek studi ini meliputi ahli oleh dosen program studi BK Universitas Sultan Ageng Tirtayasa, Bapak Arga Satrio Prabowo, M.Pd dan SMA Muhammadiyah Se-DKI Jakarta yang meliputi:

Tabel 1. Subjek Uji Lapangan

\begin{tabular}{ll}
\hline & Nama Sekolah \\
\hline SMA Muhammadiyah 01 & SMA Muhammadiyah 12 \\
SMA Muhammadiyah 02 & SMA Muhammadiyah 13 \\
SMA Muhammadiyah 03 & SMA Muhammadiyah 14 \\
SMA Muhammadiyah 04 & SMA Muhammadiyah 15 \\
SMA Muhammadiyah 05 & SMA Muhammadiyah 16 \\
SMA Muhammadiyah 11 & SMA Muhammadiyh 18 \\
SMA Muhammadiyah 23 & SMA Muhammadiyah 24 \\
\hline
\end{tabular}

Studi dan pengembangan ini menggunakan lembar penilaian yang meliputi data kualitatif dan data kuantitatif sebagai metode pengambilan data. Data kuantitatif merupakan daftar ceklis, adapun data kualitatif merupakan uraian saran dan komentar pada bagian akhir lembar penilaian.

Alat pengumpulan data yang digunakan yaitu lembar penilaian. Pada daftar ceklis meliputi 5 aspek yaitu kelayakan isi, kelayakan penyajian, bahasa, penilaian pendekatan komik sesuai dengan penilaian bimbingan dan konseling, dan kelayakan kegrafikan menggunakan skala likert. Aspek-aspek tersebut sesuai dengan Depdiknas 2008 dan PP No 19 tahun 2005 BAB 7 Pasal 43 No 5. Lembar penilaian ini disebarkan langsung ke sekolah dan menghubungi dosen bersangkutan melalui email untuk uji ahli pada bulan 19 April sampai dengan 30 Juni 2021. Teknik analisis 
deskriptif dengan menggunakan statistik deskriptif merupakan teknik analaisis data yang digunakan. Dimana Skor yang diperoleh dari lembar penilaian kemudian dikonversikan untuk mengetahui persentase kelayakan, persentase tersebut ditentukan dengan rumus sebagai berikut (Arikunto, 2006):
Kelayakan \% = Skor yang diperoleh $-\mathrm{X} 100 \%$

Skor maksimal yang dapat diperoleh

\section{HASIL TEMUAN}

Studi dan pengembangan ini menghasilkan Modul Komikadp untuk studi SMA. Pada tahap define dihasilkan analisis awal dan lembar penilaian yang akan digunakan nantinya.

Gambar 1.

Penggalan Lembar Penilaian

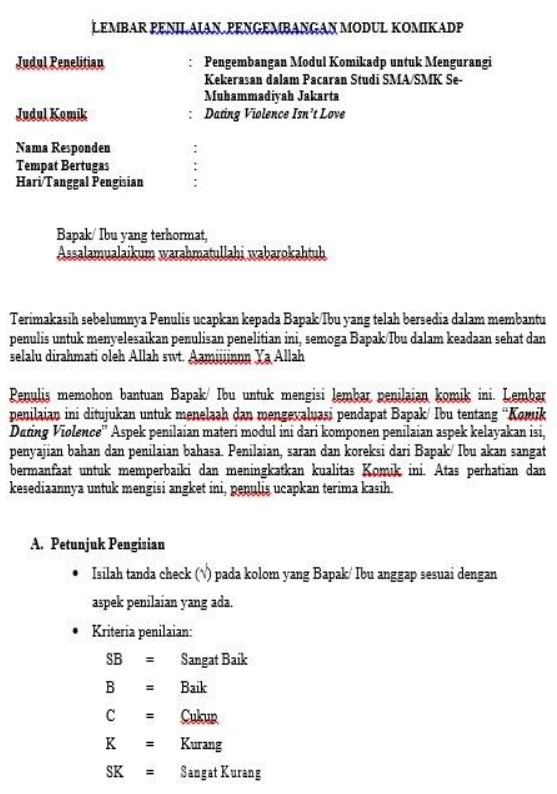

Untuk hasil analisis awal dilakukan need asessment dengan wawancara. Hasil wawancara tersebut menunjukan bahwa ada beberapa siswa yang memiliki hubungan romantis di beberapa sekolah, diantara beberapa sekolah ada yang cukup terbuka menyampaikan mengalami kekerasan dalam pacaran emosional seperti pelanggaran kebebasan. Pada tahap design

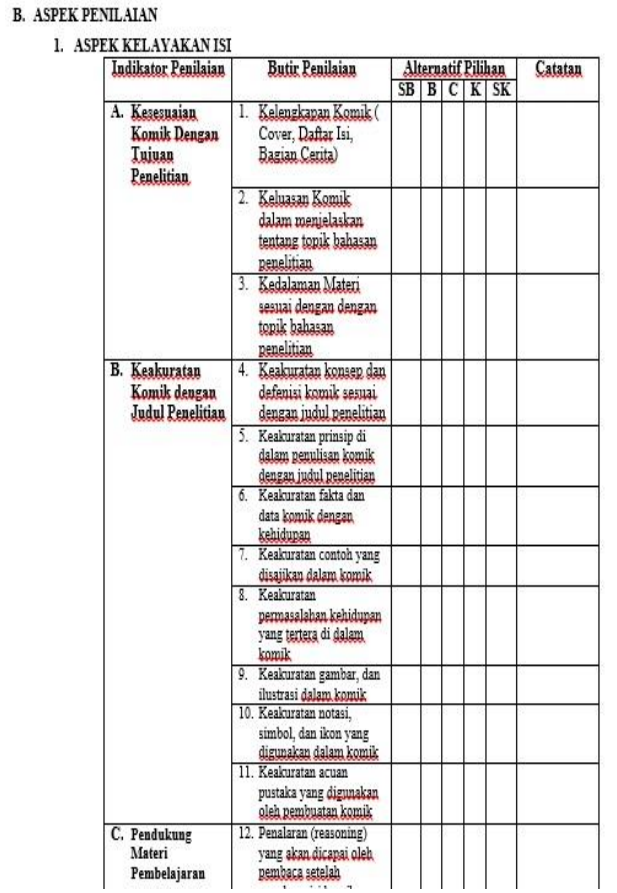

dihasilkan prototype awal Modul Komikadp. Berikut merupakan salah satu penggalan Komikadp yang ada di dalam Modul Komikadp: 
Gambar 2.

Penggalan Komikadp yang Ada di Dalam Modul Komikadp

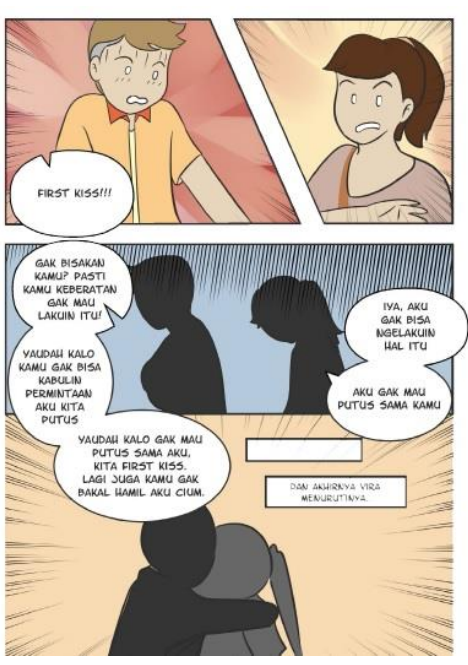

Selanjutnya tahap develop atau pengembangan, prototype yang sudah melalui tahap sebelumnya dilakukan uji ahli oleh bapak Arga Satrio M.Pd dan uji lapangan oleh guru SMA Muhammadiyah Se-DKI Jakarta.

Hasil uji ahli diketahui memiliki penilaian kelayakan isi sebesar $92 \%$ yang dikategorikan sangat layak, kelayakan penyajian sebesar $85,30 \%$ yang dikategorikan sangat layak, Penilaian bahasa sebesar 93,30\% yang dikategorikan sangat layak, penilaian pendekatan komik sesuai dengan bimbingan dan konseling

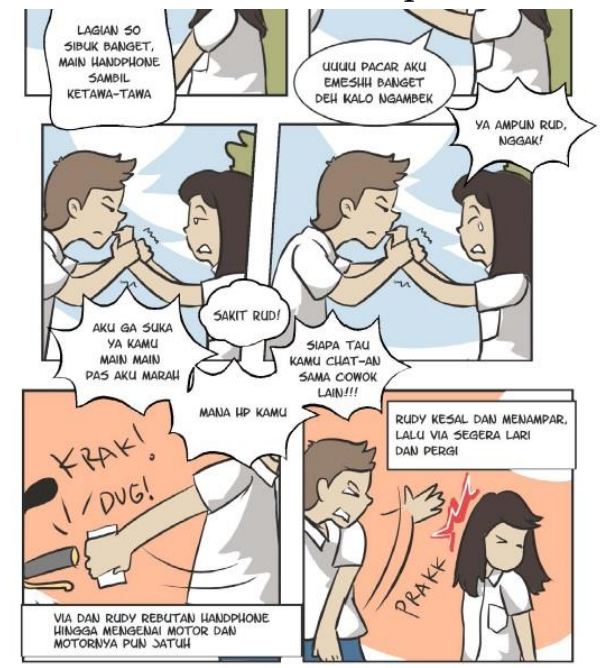

sebesar $86,60 \%$ yang dikategorikan sangat layak, dan aspek kegrafikan dengan nilai $92,20 \%$ yang dinilai sangat layak. Berdasarkan penilaian aspek-aspek tersebut bisa diketahui bahwa Modul Komikadp sangat layak. Komentar yang diberikan yaitu komik pada modul Komikadp sudah layak dan perlu cerita berkelanjutan supaya tidak berhenti pada cerita-cerita yang ada. Ketetapan akhir pada tahap uji ahli yaitu berterima, tepat, dan layak sehingga dapat digunakan sebagai dasar untuk melaksanakan tahap selanjutnya tanpa perbaikan.

Table 2. Persentase Kelayakan Modul Komikadp Peraspek Berdasarkan Uji Lapangan

\begin{tabular}{lcc}
\hline \multicolumn{1}{c}{ Aspek } & Persentase & Kategori \\
\hline Kelayakan Isi & $83 \%$ & Sangat layak \\
Kelayakan Penyajian & $84,66 \%$ & Sangat Layak \\
Penilaian Bahasa & $85,33 \%$ & Sangat Layak \\
Penilaian Pendekatan Komik Sesuai dengan & $82,22 \%$ & Sangat Layak \\
Penilaian Bimbingan dan Konseling & & \\
Kelayakan Kegrafikan & $81,61 \%$ & Sangat Layak \\
\hline
\end{tabular}


Adapun penilaian di lapangan bisa dilihat pada Tabel 2, hasil penilaian tersebut menunjukan semua aspek pada modul Komikadp dikategorikan sangat layak. Sayangnya, keterbatasan waktu dan biaya pada studi dan pengembangan ini menjadi kendala, sehingga tidak sampai pada tahap dissemiinate (penyebaran).

\section{PEMBAHASAN}

Berdasarkan studi yang sudah dilakukan, telah dihasilkan Modul Komikadp yang dinilai sangat layak secara uji ahli dan uji lapangan. Pada modul ini terdapat Komikadp yang berisi contoh kasus kekerasan dalam pacaran yang disampaikan, secara uji ahli kegrafikannya dinilai sangat layak. Sesuai dengan studi yang dilakukan oleh (Nugraha, 2020) di Semarang tentang "Pengembangan Komik Kimia sebagai Media Pembelajaran Berbasis CET (Chemo-Edutaintment)" studi ini menunjukan kreativitas dan hasil belajar peserta didik salah satunya dipengaruhi media komik.

Selain Komikadp juga terdapat susunan materi-materi dan petunjuk yang bisa membuat modul ini user friendly. Sesuai studi terdahulu yang dilakukan oleh (Khoiriyah \& Habsy, 2018) “Pengembangan Modul Komik Pendidikan Kesehatan Reproduksi Terhadap Peningkatan Pengetahuan dan Sikap Remaja Tentang Dampak Seks Pranikah di SMAN 2 Singaraja Kabupaten Buleleng Provinsi Bali" Hasil dari studi yaitu peningkatan pengetahuan dan sikap remaja salah satunya dipengaruhi oleh pemberian leaflet dan modul komik tentang akibat seks. Hal ini mempertegas studi yang dilakukan bahwa modul komik berpengaruh terhadap peningkatan pengetahuan dan sikap remaja.

Pada modul Komikadp juga menghadirkan materi bahwa kekerasan dalam pacaram sendiri adalah hal yang penting untuk dicegah dientaskan. Sesuai studi yang dilakukan oleh (Ustunel, 2019) di Turki tentang "A Feminist Approach to Dating Violence Prevention: Creating Change Toward a safety, Equalitynd Mutuality" tujuan dari studi ini adalah mengisi kesenjangan ini dengan merancang program pencegahan kekerasan dalam pacaran dari pendekatan feminis dan untuk menyelidiki proses perubahan dengan metodelogi teori dasar konstruktvs. 56 mahasiswa Turki menyelesaikan program dan berpartisipasi dalam wawancara individu semi terstruktur. Studi ini berpendapat bahwa pendekatan feminis terbukti menjadi kerangka kerja yang berguna untuk upaya pencegahan kekerasan dalam pacaran dan diakhiri dengan rekomendasi untuk pekerjaan pencegahan di masa depan. Namun sayangnya, studi ini baru memfokuskan pada mahasiswa dan orang dewasa. Sedangkan studi yang dilakukan saat ini, memfokuskan kepada siswa sebagai sasaran layanannya.

Selain menampilkan pentingnya mengentaskan kekerasan dalam pacaran, mencegah kekerasan dalam pacaran merupakan hal yang penting dan juga terdapat dalam modul Komikadp Sejalan dengan studi yang dilakukan oleh (José et al., 2020) tentang "Effectiveness of a Mobile 
App Intervention to Prevent Dating Violence in Residental Child Care" di Valencia. Tujuan dari studi ini untuk mengurangi keyakinan dan sikap maladaptif yang terkait dengan kekerasan dalam pacaran: disorsi atau mitos tentang cinta romantis dan dimensi seksisme yang bermusuhan. Peserta merupakan 71 remaja dari 9 rumah kelompok di Valencia (Spanyol). Instrumen yang digunakan ASI (Ambivalent Sexism Inventory), AMI (Ambivalence Against Men Inventory), dan mitos tentang cinta romantis. Hasilnya, kelompok eksperimen menunjukan perubahan signifikan lebih dari kelompok kontrol pada semua tindakan. Hasil ini menunjukan bermanfaat bagi profesional yang terlibat dalam perawatan anak dan remaja, yang dapat mengambil keuntungan dari kecenderungan remaja terhadap komunikasi online. Namun studi tersebut belum diterapkan di sekolah dan belum menggunakan media.

Mengingat hal tersebut, di sekolah diperlukan peran Bimbingan dan Konseling. Pencegahan dan pengentasan melalui layanan Bimbingan dan konseling merupakan salah satu fungsi Bimbingan dan Konseling (Amti, 2008). Cara meningkatkan kualitas pemberian layanan diantaranya menggunakan media (Zaini et al., 2020). Media dalam BK merupakan hal yang penting (Amti, 2008). Peran media untuk dapat meningkatkan tingkat keefektifan tujuannya dibutuhkan pada bentuk komunikasi layanan Bimbingan dan Konseling (Prasetiawan, 2017). Media juga membantu pelaksanaan layanan Bimbingan dan Konseling yang tidak tatap muka langsung (Prasetiawan, 2017). Salah satu media yang bisa digunakan yaitu modul. Menurut Arum salah satu karakteristik modul yang baik adalah User friendly (Lara, 2021). Selain itu menurut (Pohan \& Siregar, 2020) modul merupakan salah satu media pelayanan BK yang efektif karena disusun berdasarkan need assessment dari klien itu sendiri. Disisi lain lebih banyak solusi kreatif pada tes transfer $89 \%$ apabila menggunakan kata-kata dan gambar dibandingkan siswa yang hanya belajar dengan kata-kata saja merupakan teori kognitif multimedia learning Mayer (Suparman et al., 2020). Komik edukatif dalam hal ini Komikadp yang berada dalam Modul Komikadp adalah media yang fleksibel bagi remaja, karena memiliki bahasa visual yang universal (Anwar, 2020). Meskipun demikian, mengingat empat tahapan yang digunakan dalam studi ini. Untuk lebih sempurnanya modul ini digunakan tentunya masih memerlukan penelitian lanjutan untuk tahap disseminate pada cakupan yang lebih luas.

\section{SIMPULAN}

Berdasarkan hasil pengembangan Modul Komikadp dinilai sangat layak digunakan oleh Guru BK/ Konselor sebagai salah satu media dalam mengurangi kekerasan dalam pacaran pada Siswa SMA. $\mathrm{N}$, mengingat empat tahapan yang digunakan dalam studi ini. Masih memerlukan penelitian lanjutan untuk tahap disseminate. 


\section{UCAPAN TERIMA KASIH}

Terimakasih kepada SMA

Muhammadiyah Se-DKI Jakarta dan Bapak Arga Satrio Prabowo M.Pd yang sudah berkenan menjadi subjek penelitian dan pengembangan ini.

\section{DAFTAR PUSTAKA}

Amti, P. dan E. (2008). Dasar-dasar bimbingan dan konseling. Rineka Cipta.

Anik Nur Khaninah, M., \& Widjanarko. (2016). Perilaku agresif yang dialami korban kekerasan dalam pacaran. 15(2), 151-160.

Anwar, A. K. (2020). Developing students' worksheet based educational comic for eleventh grade of vocational high school agriculture. 1(1), 1-12.

Arikunto, S. (2006). Prosedur penelitian suatu tindakan praktik. Jakarta: Rineka Cipta.

Carrascosa, L., \& Ortega-bar, J. (2020). Relations among romantic myths, O ffl ine dating violence victimization and cyber dating violence victimization in adolescents. Dv, 11-15.

Cava, M., Buelga, S., \& Carrascosa, L. (2020). Computers in human behavior sexist attitudes, romantic myths, and offline dating violence as predictors of cyber dating violence perpetration in adolescents. 111(June). https://doi.org/10.1016/j.chb.2020.1064 49.

Duval, A., Lanning, B. A., \& Patterson, M. S. (2018). A systematic review of dating violence risk factors among undergraduate college students. https://doi.org/10.1177/1524838018782
207.

José, J., Barry, H., \& Care, R. C. (2020). Psychosocial intervention effectiveness of a mobile app intervention to prevent dating violence in.

Khoiriyah, K., \& Habsy, B. A. (2018). Keefektifan konseling kelompok rational emotive behavior untuk meningkatkan self esteem siswa SMA. Perspektif Ilmu Pendidikan. https://doi.org/10.21009/pip.322.5

Lara, S. (2021). Pengembangan modul pembelajaran IPS berbasis karakter pada kelas $V$ sekolah dasar. Universitas Bung Hatta.

Maharsi, I. (2011). Komik dunia kreatif tanpa batas (1st ed.). Kata buku.

Ni Ketut Ayu Wulandari, Luh Ayu Purnami, A. K. R., \& Kresnayana, M. Y. (2020). Pengembangan modul komik pendidikan kesehatan reproduksi terhadap peningkatan pengetahuan dan sikap remaja tentang dampak seks pranikah di SMA N 2 Singaraja Kabupaten Buleleng Provinsi Bali. 5(1), 176-183.

Nugraha, A. (2017). Pengembangan media komik motivasi berprestasi sebagai layanan bimbingan pribadi bagi siswa SMP Muhammadiyah 1 Godean. Jurnal Riset Mahasiswa Bimbingan Dan Konseling, 3(6), 465-473.

Nugraha, D. A. (2020). Pengembangan komik kimia sebagai media pembelajaran berbasis CET (ChemoEdutainment). School Science and Mathematics, 2(3), 133-139. https://doi.org/10.1111/j.19498594.1902.tb00418.x

Pohan, R. A., \& Siregar, M. (2020). Need 
assesment of guidance and counseling module to improve freshmen selfadjustment. Biblio Couns : Jurnal Kajian Konseling Dan Pendidikan, 3(3), 113-119.

https://doi.org/10.30596/bibliocouns.V 3I3.5221.

Prasetiawan, H. (2017). Media dalam layanan bimbingan dan konseling. February, 1529-1536.

Safira, D. (2019). Membunuh hantu-hantu patriarki (S. Banggai (ed.); 1st ed.). Jalan Bary.

Sugiyono. (2013). Metode penelitian kuantitatif, kualitatif, dan RED (19th ed.). Alfabeta.

Suparman, I. W., Eliyanti, M., \& Hermawati, E. (2020). Pengaruh penyajian materi dalam bentuk media komik terhadap minat baca dan hasil belajar. Pedagogi: Jurnal Penelitian Pendidikan, 7(1), 5764.

https://doi.org/10.25134/pedagogi.v7i 1.2860 .

Thiagarajan, S. (1974). Instructional development for training teachers of exceptional children: A sourcebook.

Ustunel, A. O. (2019). A feminist approach to dating violence prevention: Creating change towards safety, equality and mutuality.

2.

https://doi.org/10.1177/0959353519882 462.

Wekerle, C., \& Wolfe, D. A. (1999). Dating violence in mid-adolescence: Theory, significance, and emerging prevention initiatives. Clinical Psychology Review. https://doi.org/10.1016/S02727358(98)00091-9.
World Health Organization. (2021). Violence against women.

Wulandari, P. (2013). Kekerasan dalam pacaran. In Journal of Chemical Information and Modeling.

Zaini, A., Dianto, M., \& Mulyani, R. R. (2020). Pentingnya penggunaan media bimbingan dan konseling dalam layanan informasi. Prosiding Seminar Nasional Bimbingan dan Konseling Universitas Negeri Malang, 1986, 126131. 